\title{
Esophagus and Esophagogastric Junction Cancer pT2 TNM Finding v8
}

National Cancer Institute

\section{Source}

National Cancer Institute. Esophagus and Esophagogastric Junction Cancer pT2 TNM

Finding v8. NCI Thesaurus. Code C133380.

Esophagus and esophagogastric junction cancer with tumor invading the muscularis propria. (from AJCC 8th Ed.) 